\title{
WILL YOU MISS ME WHEN I AM GONE? THE ECONOMIC CONSEQUENCES OF ABSENT PARENTS
}

\author{
Marianne E. Page \\ Ann Huff Stevens \\ Working Paper 8786 \\ http://www.nber.org/papers/w8786
NATIONAL BUREAU OF ECONOMIC RESEARCH
1050 Massachusetts Avenue
Cambridge, MA 02138
February 2002

\begin{abstract}
We would like to thank seminar participants at Indiana University-Purdue University Indianapolis, the Joint Center for Poverty Research, National Bureau of Economic Research, Syracuse University, University of Michigan, University of Toronto and University of Wisconsin. Much of the work on this project was completed while Page was a Visiting Scholar at the Joint Center for Poverty Research. The views expressed herein are those of the authors and not necessarily those of the National Bureau of Economic Research.
\end{abstract}

(C) 2002 by Marianne E. Page and Ann Huff Stevens. All rights reserved. Short sections of text, not to exceed two paragraphs, may be quoted without explicit permission provided that full credit, including (C) notice, is given to the source. 
Will You Miss Me When I Am Gone? The Economic Consequences of Absent Parents Marianne E. Page and Ann Huff Stevens

NBER Working Paper No. 8786

February 2002

JEL No. I3, J3

\begin{abstract}
This paper examines the effects of family structure on the economic resources available to children, using family fixed-effects to control for unobservable characteristics of the family. The effects of divorce on the income and consumption of children born to two-parent households, and the effects of marriage on children born into single-parent households are both considered. In the long-run(six or more years after the most recent divorce) family income falls by 40 to $45 \%$ after divorce, and food consumption is reduced by $17 \%$. Six or more years after the most recent marriage, income of children born to single parents rises by 50 to $57 \%$, but there is no statistically significant increase in food consumption. These

estimates are substantially less than the difference in income implied by cross-sectional comparisons of different family types. When income changes are measured according to time since the parents first divorce, there is substantial recovery in income, virtually all of which is explained by subsequent remarriages. Similarly, when we look at income several years after a parent's first marriage, the gain is 28 to $33 \%$, reflecting the short-lived nature of many of these marriages.
\end{abstract}

Marianne E. Page Department of Economics University of California, Davis

One Shields Avenue Davis, CA 95616-8578

mepage@ucdavis.edu
Ann Huff Stevens

Department of Economics

Yale University

Box 208269

New Haven, CT 06520

and NBER

ann.stevens@yale.edu 


\section{Introduction}

Over the past fifty years the number of single-parent families in the United States has skyrocketed. Between 1960 and 1995, the number of children living apart from one of their parents increased from $12 \%$ to almost $40 \%$ (McLanahan, 1997), the rate of divorce increased by over $200 \%$ (Friedberg, 1998) and the fraction of children born outof-wedlock rose from about 5\% to over 30\% (Cancian and Reed, 2000). Half of all American children today are expected to spend part of their childhood in a family headed by a mother who is divorced, separated, unwed or widowed (Bumpass and Raley, 1995).

What does this change in family structure mean for American children? In particular, to what extent are the economic resources available to children living in single-parent families compromised by the absence of a second cohabitating adult? Social scientists often assess the "effect" of family structure on economic well-being by comparing the average income among two-parent families to the average income of single-parent families (McLanahan and Casper, 1995; Spain and Bianchi, 1996; Waite, 1995). These studies unequivocally show that family structure is substantially related to economic well-being, and are often cited by those who advocate for societal and legal changes that would strengthen marriage (e.g. Whitehead, 1996). In spite of their wide use, however, these types of statistics are unable to tell us how much of the observed gap is actually caused by the absence of a second parent. Cross-sectional comparisons across family types do not necessarily indicate how single-parent families would fare were they to become two-parent families because other factors may be partly responsible for the variation in resource levels. 
The causal effect of family structure on a family's economic resources has important implications for public policy. In recent years, the belief that marriage bestows large economic gains has generated enthusiasm for policy proposals that encourage the formation and continuation of two-parent families (Gallager, 1996; Galston, 1996; Ooms, 1996; Popenoe, 1996; Waite, 1995; Whitehead, 1996). This enthusiasm has lead to several policy changes: the states of Arizona, Arkansas and Louisiana, for example, have created "covenant marriages," in which couples agree at the time they are married to conditions that make it harder for them to divorce. ${ }^{1}$ In addition, about three quarters of states have broadened the eligibility criteria for the Temporary Assistance to Needy Families (TANF) program to include two-parent families. TANF's former incarnation as the Aid to Families with Dependent Children program (AFDC)), was targeted towards single-parent families on the grounds that children in such families suffer economic losses as a direct result of their parents' marital status. If the losses to children growing up in single-parent families are small, then the grounds for this type of targeting may be tenuous. If these losses are large, however, then targeted cash assistance may be an appropriate means of mitigating them.

This study has three goals. Our first goal is to estimate how much the economic status of single-parent children could be improved if they lived with both of their parents. We accomplish this task by estimating a dynamic model with longitudinal data that allows us to incorporate family-specific fixed effects. We look separately at the impact of divorce and out-of-wedlock childbearing. Although other studies have estimated changes in family income following divorce, they have focused on comparisons of pre-

\footnotetext{
${ }^{1}$ Legislation for covenant marriages has also passed one house in Georgia, Oklahoma, Oregon and Texas.
} 
divorce to post-divorce resources, which do not take life-cycle earnings growth into account, and are thus likely to underestimate the true loss. To our knowledge, there have been no studies that have used a fixed effects model to estimate the resource costs associated with being born to a single parent.

Our dynamic model also allows us to trace out the losses associated with singleparent status over an extended time interval. Children whose parents divorce, for example, may experience a short-term income reduction that is recouped in later years when their mothers remarry or become more active labor force participants. Quantifying the time-path of economic losses following a divorce or out-of-wedlock birth is particularly important in the wake of TANF, which places a five year life-time limit on receipt of benefits, and requires that participants become members of the labor force within two years of initiating benefits. If the costs of growing up in a single-parent family persist for many years, then these time limits may have serious implications for children's well-being.

Finally, we use our model to examine how family structure affects the components of income over time. We look separately at changes in fathers' earned income, mother's earned income, child support and alimony payments, and welfare income. This exercise allows us to see how families modify their behavior in response to a change in marital status.

We find that controlling for unobservable family background characteristics is important. Simple cross-sectional family income comparisons between children born out-of-wedlock and children born into two-parent families, for example, are almost 1.8 times bigger than our estimated cost of being born to a single mother. OLS regressions 
produce coefficient estimates of the effects of marriage that are more than twice as large as our fixed-effects estimates. Nevertheless, even after controlling for unobservables, we estimate large family structure effects. Our dynamic analysis also shows that the gains associated with marriage fall somewhat over time for children born out-of-wedlock and that the initial losses experienced by children whose parents divorce are partially recovered in later years. Most of this recovery is explained by the fact that a substantial fraction of divorced mothers remarry. Finally, our dynamic income decompositions suggest that families' respond to the absence of a second parent in a variety of ways that help mitigate some of the costs.

\section{Estimating the Cost of Growing Up in a Single Parent Family}

\subsection{Background}

It is well known that children growing up in single-parent families have fewer economic resources than children living in two-parent families. In 1999, for example, median family income for a two-parent family with children was $\$ 60,296$, whereas median family income for a female-headed family with children was $\$ 22,418$ (Census Bureau, March 2000 CPS). McLanahan and Sandefur (1994) estimate similar differences in assets across family types: using the PSID, they find that while $98 \%$ of two-parent families with an adolescent child own their own car, only $70 \%$ of similarly defined single-parent families own a car. Likewise, only $50 \%$ of such families own their home, whereas $87 \%$ of two-parent families (with an adolescent) are home-owners. Many believe that these differences in resources can explain a significant part of the well documented differences in socioeconomic outcomes between adults who grew up in two 
parent families and adults who grew up in single parent families. McLanahan and Sandefur, (1994), for example, attribute half of the difference in outcomes to differences in family income.

Cross-sectional comparisons of income across different family types can be misleading, however. Table 1 shows that even prior to marital dissolution average family income and consumption are lower for families that will eventually go through divorce than for families that will remain intact. This suggests that part of the income difference across family types may exist for reasons other than differences in family structure. Previous researchers have noted this problem, but have struggled to address it ${ }^{\mathrm{Q}}$, particularly when assessing the economic consequences for children born out-ofwedlock - the only estimates we have been able to find for these children are simple cross-sectional comparisons like those discussed above. Researchers have typically estimated the costs of divorce by comparing changes in economic resources across two time periods, before and after a divorce occurs (for a review, see Holden and Smock, 1991; also McLanahan and Sandefur, 1994), but while cross-sectional comparisons are likely to overstate the effect of family structure on economic resources, estimates based on simple "before and after" comparisons are likely to be downward biased since they do not control for life-cycle earnings growth. Most of these studies do not include a control

\footnotetext{
${ }^{2}$ It is important to note that there is debate about the extent to which income affects children's outcomes. Mayer (1997), for example, uses different methods and finds little evidence that income plays a role in children's outcomes.

${ }^{3}$ Smock, Manning and Gupta (1999) attempt to deal with the selection problem by estimating endogenous switching regression models. Their exclusion restrictions include whether the respondent (wife) worked full-time prior to the divorce, whether she lived with both her biological parents before age 14, her mother's educational attainment, age at the time of the marriage, duration of marriage and whether the marriage was a first marriage for both spouses. The authors argue that these variables predict the likelihood
} 
group. Another drawback is that when the comparisons are restricted to only two points in time they overlook the possibility of dynamic adjustments to changes in marital status. The few studies that examine the time-path of economic resources following divorce (Bane and Weiss, 1980; Butrica, 1998; Duncan and Hoffman, 1985a, 1985b; Peterson, 1989; Stirling, 1989, Weiss, 1984) are typically based on non-representative, dated samples. ${ }^{\boxplus}$ More important, none of them employ regression analysis, so they are unable to control for what income growth would have been in the absence of the divorce or to control for other factors that may be changing over time.

Duncan and Hoffman (1985a, 1985b) (with a follow-up by Butrica, 1998) provide the most comprehensive dynamic study to date. Using the PSID, they trace out family income for a sample of children between the ages of one and five in the year prior to their parents' divorce, from the year before the divorce until five years after the divorce. Their study is based on divorces or separations that occurred between 1969 and 1975. The divorced sample's income in the years around the marital dissolution is compared to income for a sample of children in continuously married families between 1971 and 1977. Duncan and Hoffman find that the average income of children whose parents' divorce or separate falls by about $30 \%$ in the year after the divorce, but that within five years of the marital dissolution, their average income is close to its pre-divorce level. Most of this recovery can be explained by high rates of remarriage: for children whose mothers' remain unmarried throughout the observation period, income levels remain

of marital disruption. These variables are also likely to be correlated with income, however.

${ }^{4}$ Bane and Weiss (1980) and Weiss (1984), for example, restrict their analysis to a sample of women who remain unmarried. Peterson (1989) focuses on women aged 30-44 in 1967. Stirling (1989) looks only at women who have been divorced for at least five years. 
about $30 \%$ below their initial levels. Furthermore, although children whose mothers' remarry regain their previous levels of income, they never catch up to their peers whose parents remain married because incomes in continuously married families grow throughout the period.

Our study is similar in spirit to that of Duncan and Hoffman, but it goes beyond their work by employing a more comprehensive statistical methodology. Our empirical framework allows us to control for income growth over the life-cycle, which enables us to estimate the effect of divorce on economic resources relative to what they would have been if the divorce had not taken place. We are also able to allow for differences in income growth across family types, and to control for macroeconomic factors whose omission may bias previous estimates. Our study extends Duncan and Hoffman's sample by 12 years, and includes children between birth and age 16 instead of between the ages of 1 and 5. Focusing on young children (and, therefore, young parents) could lead to biased estimates of the average divorce effect since earnings growth is steeper among young workers and since mothers' labor supply is lowest when their children are young.

To our knowledge, there have been no attempts to take unobservables into account when estimating the economic losses experienced by children who are born outof-wedlock. Cross-period comparisons have not been applied to this group, presumably because it is difficult to come up with an appropriate "initial" period. Our model can be extended to provide such estimates, however. Using a sample of children born into single-parent families, we estimate the economic gains experienced by some of the children when their mothers marry and interpret the negative of these estimates as upper 
bounds on the loss associated with single-parent status. If women who marry have larger potential gains to marriage than those who do not marry, then our estimates will overstate the gains to marriage for the typical out-of-wedlock child, but they will still be lower than the cross-sectional statistics that are currently cited because they will be based on a model that controls for fixed effects.

\subsection{Econometric Model}

Our basic approach is to use a fixed-effects estimator to control for unobserved family characteristics that may be correlated with divorce and marriage probabilities, using data for children whose parents' marital status changed at some point during our observation window and a comparison group of children whose parents' marital status did not change during the period. Specifically, given longitudinal data on family resources and marital histories, the effects of divorce on the economic resources available to children can be modeled in the following way:

$$
\ln I_{i t}=X_{i t} \beta+D_{i t} \delta+\alpha_{i}+\gamma_{t}+u_{i t}
$$

where $\mathrm{I}_{\mathrm{it}}$ is a measure of the economic resources available to child $i$ in year $t, \mathrm{X}_{\mathrm{it}}$ is a vector of child/family specific variables that vary over time and that may be correlated with the child's economic status, and $\mathrm{D}_{\mathrm{it}}$ is a vector of dummy variables indicating that a divorce has taken place in a future, current, or previous year. The error term has three components, a child-specific fixed effect, $\alpha_{i}$, a year-specific effect, $\gamma_{t}$, and a random component, $u_{i t}$.

\footnotetext{
${ }^{5}$ Since mothers' labor supply has been increasing over time, the divorce effect may be smaller in more recent years. Our ability to include 12 additional years of data, may therefore affect the average estimates as well.
} 
The vector of divorce indicators $\left(D_{i t}\right)$ contains three types of variables: dummy variables that equal one in the years prior to the divorce, a dummy variable equal to one in the year that the divorce takes place, and a series of dummy variables indicating that a divorce took place in a previous year. The first set of indicator variables captures the possibility that family resources may begin to deteriorate prior to the actual divorce. This might happen if, for example, a divorce is precipitated by a parent's job loss: failure to include "years prior" dummies would lead to a biased estimate of the effect of the divorce. Our model, therefore, includes a dummy variable for each of the two years preceding the divorce. The dummy variable indicating the year of the divorce captures the immediate effect of the divorce on family income and consumption, whereas the coefficients on the set of variables indicating that a divorce has taken place in a previous year will reflect the persistence of the divorce effect over time. Two methods will be used to define these post-divorce indicators. Initially, these variables will refer to the years that have elapsed since the child first experienced his parents' divorce. Later, we will define the variables with respect to years since the most recent divorce. We follow the post-divorce period for six years, including a dummy variable indicating that six or more years have elapsed since the divorce took place.

The error term in the above equation contains a time-invariant child-specific effect, $\alpha_{i}$, which captures anything about the child's family that is constant over time. Since most children in single parent families live with their mothers, this variable will primarily pick up characteristics of the child's mother that may be correlated with both divorce probabilities and the family's resources. If mothers with lower earnings capacity are more susceptible to divorce, then estimates of divorce effects that fail to control for 
$\alpha_{i}$ will be biased towards finding larger losses. As discussed above, other studies have estimated the resource losses associated with divorce by comparing family resources in a particular period before the divorce to family resources in a particular period after the divorce, but unless the change in resources is compared to an appropriate control group the estimates produced using this method will not tell us how much better off children would be if their parents had remained together. Furthermore, the approach may overstate or understate the average annual losses associated with the event, depending on which "before" and "after" years are chosen. The advantage of the model we employ is that it traces out the economic consequences in each year following the divorce and allows us to estimate both the short-term and long-term effects, which may differ.

Because this model includes fixed effects, the variables in $\mathrm{X}$ that do not vary over time, such as race and mother's education, are eliminated from the model. The only variables included in $\mathrm{X}$ are the child's age, his age squared and family size. ${ }^{\square}$ Equation (1) also includes a vector of calendar-year dummy variables $\left(\gamma_{t}\right)$. These variables will control for economy-wide income and consumption changes over time, including both business cycle effects and trends in income and consumption over the period we study.

Unbiased estimates of the economic consequences of being born into a singleparent family are even more elusive than unbiased estimates of divorce effects because unlike the case of divorce there is no obvious "before" period to compare the singleparent family's resources. As a result, existing information is limited to simple crosssectional comparisons. We propose an alternative way of estimating these losses that

\footnotetext{
${ }^{6}$ In the consumption regressions we also control for the family's "food needs," which is a variable created by the PSID to measure the caloric needs of the family, accounting for family size, sex, and the age of the family members.
} 
allows us to incorporate family fixed effects. Specifically, using a longitudinal sample of children born out-of-wedlock we can estimate the parameters of the following model $\ln I_{i t}=X_{i t} \beta+M_{i t} \delta+\alpha_{i}+\gamma_{t}+u_{i t}$

Where $\mathrm{M}_{\mathrm{it}}$ is a vector of dummy variables indicating that a marriage has taken place in a future, current, or previous year. The negative of these parameters can be interpreted as the loss associated with remaining in a single-parent family that was formed by an out-ofwedlock birth. This model is essentially the inverse of equation (1) in that it compares changes over time in the resources available to children whose parents' married at some point during our observation window to changes over time in the resources of children whose parents remained single. The advantage of this approach is that it allows us to control for unobservable child/family specific factors that may be correlated with both marital decisions and economic status.

Our estimates of $\delta$ provide information on the effects of changes in family structure on the children who experience them. In the language of Heckman, LaLonde, and Smith (1999) we estimate the effect of "treatment on the treated." If the impact of divorce or marriage would be different for children whose family structure remains constant over time then $\hat{\delta}$ will be a biased estimate of the average effect that divorce or marriage would have on the population. For example, if the gains to marriage are larger for women who choose to marry than for women who choose not to marry then our estimates of $\delta$ will be upward biased estimates of the costs to children of growing up in a single-parent family formed by an out-of-wedlock birth. We show, however, that even with this upward bias our estimates are substantially smaller than estimates that do not control for fixed effects. Furthermore, they do directly apply to the majority of children 
born to single mothers, since $52 \%$ of children born to single parents have spent some time in a two-parent household by the time they reach age 15. Forty percent of these children experience at least one year in a two-parent household by the age of six.

In the case of divorce, similar issues arise; we estimate the effects of divorce among those children whose parents do actually divorce. In this case, however, it is less clear how estimates of divorce effects for the untreated group would be of interest to policymakers. We care about how much better off the "treated" children would be if their parents had not divorced. Estimates of the population-wide effect of divorce would not answer this question.

\section{Data}

Our data come from the 1968 through 1993 waves of the Panel Study of Income Dynamics, a longitudinal survey conducted by the University of Michigan's Institute for Social Research. The PSID began by interviewing a national probability sample of families in 1968 and has reinterviewed the members of those families every year since. The PSID also follows a subsample of families in poverty. We make use of both samples in order to increase the precision of the estimates. Our regressions are weighted using the individual weights for the last year in which the individual is observed.

Since our primary interest is in how family structure affects the economic resources available to children, our sample consists of children who are potentially followed from the year of birth until age 16. Our analysis is based on two samples: the first sample consists of children born into two-parent families, and the second sample consists of children born into single-parent families. We use the first sample to estimate 
the effects of divorce, and the second sample to estimate the losses associated with being born out-of-wedlock. Children who were born prior to the 1968 survey are excluded from the sample because we cannot determine whether they were born into a two-parent or single-parent family. After individuals turn 16 they are no longer followed, because we want to be sure that any observed changes in family structure are associated with their family of origin. Some PSID children are not present throughout the entire length of the survey. We include these individuals from birth until the first year they are missing data, but do not include them in any subsequent years even if they have valid data, because the missing years make it impossible to determine parents' marital status in that year, and, therefore, to accurately ascertain the number of years since a change in family structure took place.

We use three different measures of the economic resources available to the family: the log of pre-tax family income, the log of post-tax family income, and the log of family consumption. Each of these measures has its pros and cons as a measure of economic well-being. A number of researchers have argued that consumption measures are preferable to income measures because income systematically understates the financial resources available to a household, and because consumption is a more direct measure of well-being (Meyer and Sullivan, 2001). Unfortunately, consumption information in the PSID is limited to food consumption, and although food consumption is the sort of necessary expenditure that is of interest to policymakers, one might expect to see less variation in food expenditures than in almost any other consumption item: families may spend down their savings in order to maintain some threshold level of food consumption. We remain agnostic about which measure is best, and present the results 


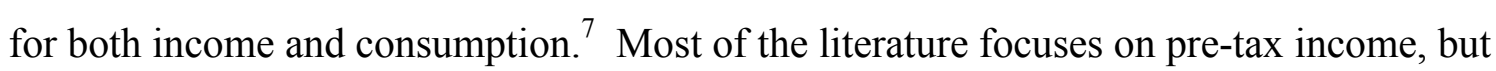
we present results for post-tax income as well since changes in the number of adult earners in the family may change the family's tax bracket. In order to account for changes in family composition that accompany resource changes, all of our regressions control for family size. We have also used income-to-needs as a dependent variable, and the estimates generated from those regressions are very similar to our income results.

Economic resources are measured at the level of the PSID family unit. This means that if children are living with both their mother and their grandparents, and the mother and grandparents are pooling resources and expenses, then the grandparent's resource contributions are included as part of what is available to the child. This seems like the appropriate way of measuring children's economic well-being since single parents' living arrangements may be chosen as a way of maximizing their resources.

The timing of the PSID questions varies across the different variables. Questions about family income clearly refer to the previous calendar year, whereas information about family structure is recorded at the point of the interview. Since a change in family structure recorded at the time of the interview may have occurred at any time in the

\footnotetext{
${ }^{7}$ Food consumption data are missing for 1973, 1988 and 1989. The PSID also includes information about expenditures on rent and mortgage payments, and utilities, but these data are missing additional years and so we do not use them. It would be difficult to compute housing consumption flows from owner occupied housing since some households have no mortgage payments.

${ }^{8}$ The results from this exercise are available from the authors.

${ }^{9}$ An exception to this is that individuals who return to an extended family home after being out on their own continue to be interviewed by the PSID as a separate family unit. For example, an adult daughter of a PSID family who returns to her parents home after having a child will continue to be counted as a head of her own household.

${ }^{10}$ Focusing on aggregate measures of resources overlooks the important question of how resources are allocated within families. It may be that economic shocks cause parents to disproportionately reduce their own consumption in order to maintain their children's
} 
previous year, we ignore the different frames of reference and match the family structure and income data from the same survey year. ${ }^{1}$ The timing of the food consumption questions is ambiguous, but Zeldes (1989) argues that it refers to the point of the interview rather than the previous year. ${ }^{2}$ Again, we match the family structure information and the consumption information from the same survey year. We eliminate observations for which income or consumption data are imputed.

A limitation of the PSID is that it is difficult to identify relationships among sample members who are not household heads. This is probably not a serious problem for the sample of children who begin life in two-parent families since the parents of most of these children are household heads or wives whose marital status is well documented, but it is potentially problematic for our sample of children born out-of-wedlock because a larger fraction of these children are living in families in which the household head is not the parent. We therefore use the PSID Relationship and Marital History files to carefully document transitions between marital (or cohabitating) states. We define a family as a two-parent family if the child's custodial parent is married or living as a couple with another adult. Our definition of divorce includes married couples who are living in separate residences and unmarried couples who had been living together but are separated. Similarly, when we refer to "marriage" among parents of children born outof-wedlock we include both legal marriage and cohabitation. These broad definitions of

consumption at its previous level. We know of no longitudinal data set that would allow us to investigate this issue, however.

${ }^{11}$ We have also conducted the analysis linking the current survey year's family structure information to the following survey year's income information and obtain very similar results.

${ }^{12}$ An exception is food expenditures paid for using food stamps. Before 1977, this is measured using average monthly food stamp expenditures last year, but after 1977 the question refers to food stamp expenditures in the month of the survey. 
two-parent families are intended to focus our analysis on the economic consequences associated with the presence of a second adult in the household, regardless of legal marital status.

After deleting observations for which the income and consumption measures are imputed or missing, the sample of children beginning life in a two-parent family contains 53,188 child-year observations, and 7,397 children, 1,352 of whom experience a parental divorce. The income sample of children born out-of-wedlock contains 12,628 child-year observations and 2,042 children, 465 of whose custodial parents marry sometime before they turn 16. These samples are slightly smaller when consumption is our dependent variable since the PSID is missing food consumption information in 1973, 1988 and 1989.

\section{Results}

\section{A. The Economic Consequences of Marital Dissolution}

In Table 1 we document why cross-sectional comparisons of children's resources might be problematic. The table provides the means of our variables in the year of the child's birth, which is before the change in family structure occurs. On the left side of the table we see that those households that will eventually experience a divorce have lower income and food consumption than those households in which the parents remain together. Parents who ultimately divorce also have less education on average, than parents who remain together, and are more likely to be black. These observable differences across families provide a hint that unobservable differences may also be correlated with both family structure and economic resources. When we use our data to run ordinary least squares regressions of family resources on marital status (controlling 
for the child's age, age-squared, race, mother's education and year dummies) we find that children living in divorced families have pre-tax income that is $55 \%$ below that of children in intact families, post-tax income that is $52 \%$ lower, and food consumption that is $27 \%$ below that of their counterparts. Table 2 shows what happens to the estimated resource loss when we take unobservable differences into account. The estimates in the left-hand columns of Table 2 are based on equation (1), and document the losses following the first divorce. The estimates on the right hand side of the table document the losses following the most recent divorce. We present Huber adjusted standard error estimates, which take into account the possibility that siblings' error terms are correlated.

Beginning with the left side of Table 2, we see that including fixed effects substantially reduces the estimated cost of divorce. Nevertheless, the decline in economic resources is still large: in the first year following a divorce, for example, pretax family income falls by about $42 \%$, post-tax income falls by $32 \%$ and food consumption declines by $29 \%$ Over most of the post-divorce years, the reduction in food consumption is around 50 and $70 \%$ of the post-tax income reduction. ${ }^{4}$ This is broadly consistent with previous studies that have estimated the elasticity of food consumption with respect to income to be between 0.6 and 0.7 .15

\footnotetext{
${ }^{13}$ The estimated "year of divorce" effect for the income measures will provide a mixture of income from before and after the divorce. For this reason, we refer to the period one year after the divorce as our first post-divorce observation. For food consumption, the timing is slightly different. The food consumption questions, as noted above, are likely to refer to the year of the survey, and so the "year of divorce" effect will capture a postdivorce period.

${ }^{14}$ Because the timing differs between the consumption and income measures, this ratio is calculated using, for example, the effect on food consumption one year after the divorce relative to income two years after the divorce.

${ }^{15}$ See Tobin (1950), Maddala (1971), Izan (1980) and Magnus and Morgan (1997) for estimates of the income elasticity of food.
} 
Over the course of the next six years, more than half of the loss in economic resources is recouped so that six or more years later, pre- and post-tax income are 15$20 \%$ lower than they would have been if the divorce had not occurred and food consumption is six percent lower than would be expected with no divorce. These estimates are notably smaller than those produced by simple before and after comparisons, which are typically weighted towards short-term losses. Using the same dataset, McLanahan and Sandefur (1994) for example, estimate that teenagers who experience a parental divorce sometime between ages 12 and 17 experience an income decline of approximately $50 \%$.

On the other hand, at first glance our estimates appear to be substantially larger than those produced by Duncan and Hoffman. Duncan and Hoffman emphasize the ratio of post-divorce to pre-divorce income and find that in the year following separation children's (pre-tax) family income is $32 \%$ lower than its pre-divorce level and that five years later it is just four percent lower than its pre-divorce level. Our estimated losses of $42 \%$ (one year) and $25 \%$ (five year) are larger because our model explicitly accounts for income growth over the life-cycle. Assuming that parents who divorce have similar income trajectories as parents who remain together, Duncan and Hoffman's estimates suggest that children whose parents divorce experience a $37 \%$ decline in income in the year following a divorce, and that five years after the divorce takes place their income is $14 \%$ lower than it would have been. The small differences between these estimates and our own may result from our ability to control for macroeconomic conditions.

Two potential explanations for the recovery pattern immediately come to mind. First, mothers' human capital investment may increase family income over time. Second, 
some mothers will remarry, thus increasing the economic resources available to their children through the addition of a spouse's earnings. About $30 \%$ of the divorced parents in our sample ultimately remarry during our observation window.

We explore this possibility on the right side of Table 2, where the estimates are based on a specification in which the divorce dummies refer to the number of years since the last divorce. For years in which the child is (because of remarriage) again in a twoparent household, all of the divorce dummies are set equal to 0 , and a dummy variable indicating that the child currently resides in a two-parent family is set equal to 1 . The coefficient estimates on the divorce dummies now indicate how much of the economic loss associated with divorce persists for children whose mothers do not remarry. We find that subsequent marriages explain a large portion of the recovery process: pre- and posttax family income of children whose mothers remain unmarried six or more years after the marital dissolution are 40 to $45 \%$ lower than they would have been if the divorce had not taken place. Among those who do not remarry, food consumption recovers more than income but six or more years later it continues to be $17 \%$ lower than if no divorce had occurred.

Previous work has emphasized that changes in family structure are a common pathway into (and out of) poverty (Bane and Ellwood, 1986). Our results can be interpreted in this light: we show that the average child whose parents divorce will experience quite modest long-run declines in economic well-being compared to estimates produced by the cross-sectional studies cited above, but that the size of the expected changes in children's income and consumption are closely tied to subsequent changes in family structure. We estimate that the average family experiences a six percent fall in 
food consumption and a 15\% reduction in after-tax income. An important reason for these relatively modest long-run reductions in income and consumption, however, is that many parents will remarry and thus restore some of the economic resources lost with divorce. For children whose parents remain unmarried, the average losses associated with divorce are much larger, ranging from 17 to over 40 percent. This emphasizes the important role that family structure plays in the material resources available to children.

\section{A.1. Robustness Checks}

One concern with the estimates presented in Table 2 is that even in the absence of divorce income may grow less rapidly among those who will eventually divorce than among those families that remain intact. If this is true, our fixed-effects estimates will overstate the reduction in income due to the divorce, since our estimates of income growth over the life-cycle are identified off of both types of families. In order to investigate this possibility, we have estimated models in which we include both a familyspecific trend and a family-specific fixed effect. These models produce no evidence that divorcing families have lower earnings trajectories than intact families. In fact, parents who ultimately divorce have slightly more positive earnings trends than those who remain together, although the difference in trends between these two groups is not statistically significant. As a result, the inclusion of family-specific trends slightly increases the estimated cost of divorce, although the estimates are generally not statistically different from those reported in Table 2.

Another potential concern is that our regression framework does not control for time-varying factors that might be correlated with both the probability of divorce and

${ }^{16}$ The divorce dummies are all set to zero for years in which the mother is married. 
family resources. If the onset of mental illness or drug abuse leads to a significant number of divorces, for example, then our estimates may still be biased. Charles and Stephens (2001) examine whether the probability of divorce is associated with job loss or the onset of a disability and find that job loss does increase the likelihood of a marital break-up. This could mean that some of the estimated losses associated with divorce are actually the effect of an earlier, precipitating event. We cannot directly investigate all possible events but we have tried to acknowledge their possible effects by including dummy variables for years prior to the divorce in order to see whether some other event could be generating the decline in income. We find no evidence that family income falls in any year prior to the divorce. Food consumption begins to fall in the year prior to the divorce, but this may simply reflect respondents' uncertainty about the time period to which the PSID question refers. We have also run regressions that include variables indicating whether the head of household has recently become unemployed or disabled, since these events are observable in the PSID, but including these controls has no substantive impact on our estimates. Finally, we have run IV regressions using an indicator for whether the family's state of residence currently has a unilateral divorce law as an instrument for divorce. Several researchers (e.g. Friedberg, 1998; Gruber, 2000; Reilly and Evenhouse, 1997) have documented a correlation between unilateral divorce laws and divorce rates. Unfortunately, virtually all of the within state variation in unilateral divorce laws occurs during the early 1970's, which means that most of the children in our sample cannot contribute to this IV identification strategy. As a result, the standard error estimates produced by our IV analysis are more than two orders of 
magnitude larger than those produced by OLS, so our IV estimates provide no information about the economic consequences of divorce.

\section{B. The Economic Losses for Children Born to Single Mothers}

Estimating the loss in economic resources for children born into single-parent families is trickier than estimating the losses associated with divorce because the event that creates the single-parent family does not provide a change in marital status to which the resources can be compared. As a result, most of what we know about the relative resources available to such children comes from cross-sectional comparisons. Table 1 indicates why this might be problematic: compared to the mothers of children born into two-parent families, the mothers of children born out-of-wedlock have typically completed lower levels of education and are much more likely to be black. Within the sample of children who are born into single-parent families there are also differences in some observable characteristics between those whose mothers eventually marry and those whose mothers do not. Single mothers who do eventually marry are less likely to have only a high school education, and are much less likely to be black. 7 Differences in the observable characteristics presented in the table may only hint at important differences in unobservable characteristics across groups. Our method of estimating the income losses associated with single parenthood allows us to control for these characteristics.

\footnotetext{
${ }^{17}$ It is worth noting that while family income is higher in the year of birth for out-ofwedlock children whose parents do not marry than for those whose parents do eventually marry, in subsequent years this reverses. For example, among children who are still in single parent families at the age of four, average family income among those who will later marry is more than $\$ 14,000$, but among those whose mothers are not observed to marry before the end of our sample average family income is about $\$ 12,000$. This pattern appears to be driven by a few outliers, and may reflect changes in living arrangements
} 
Using our sample of children born out-of-wedlock, we compare the income gains for children whose mothers eventually marry to the income gains for children whose mothers remain single, and interpret the negative of these estimates as the estimated resource loss associated with remaining in a single-parent family. The drawback to our approach is that, by using women who marry to identify the costs of living in this type of single-parent family, we will generate a type of selection bias. If there is heterogeneity in the gains to marriage and, as seems likely, those women who marry have larger gains to marriage than those who do not, our estimates will be upward biased estimates of the average income gain that would result if all out-of-wedlock mothers were to marry. However, the estimated effects are unbiased estimates of the gains to children whose parents actually do marry. As noted above, roughly half of the parents of children born out-of-wedlock will marry before the child is 15 years old.

The results of our exercise are presented in Table 3. One year after marriage pretax family income increases by $53 \%$, and post-tax income increases by $48 \%$. The effects of excluding federal taxes from income are smaller in this sample than for our sample of children born into two-parent households, which probably reflects the very low income levels of many families formed by an out-of-wedlock birth. Six or more years after the observed marriage, post-tax income is 28 percent higher than it would be if the children had remained in single-parent families.

Food consumption is estimated to increase by $17 \%$ in the year of the marriage, but immediately falls again. The effects of marriage on food consumption are very small, sometimes negative, and never statistically significant in the years following the

over time. For example, a teenage mother may live with her parents during the year her baby is born but may subsequently move out. 
marriage. This indicates a much lower elasticity of food consumption with respect to income than we found in our sample of children born into two-parent families, which probably results from the mothers' relatively lower incomes. Food consumption is likely to be maintained at some minimal level even when income is at the very low levels found in many of these single-parent households.

On the right side of Table 3 we show what happens to our estimates when we control for the possibility of initial marriages breaking up (and for subsequent marriages). In these regressions, the key variables indicate time elapsed in a two-parent household; the dummy variables are set to zero during years in which the household returns to single-parent status, and an additional dummy variable is added to these regressions indicating that a parent is currently between marriages. These results show that declining economic gains shown on the left side of the table are driven mainly by the fact that many marriages do not last: for those children whose parents remain married there is a fairly stable increase in post-tax income of between 50 and 58\%. This suggests that virtually all of the reduction in the gains to marriage occurs as a result of the original marriages breaking up.

These large income estimates suggest that children born into single-parent families suffer substantive economic losses as a direct result of their parents' marital status, and that cross-sectional differences between the resources available to these children and those available to children in two-parent families do not merely reflect differences in their parents' unobservable characteristics. At the same time, however, we find that cross-sectional comparisons will substantially overstate the potential gains from marriage. If we run a simple OLS regression controlling for age, age-squared, family 
size, mother's education, whether the child is black and calendar year, the estimated increase in income associated with marriage is much larger, at 118\%, compared to our estimated gain of 57 to $59 \%$. Further, the gain to a typical child whose mother marries at a point in time is even smaller, since many of these marriages will be short-lived.

As with our sample of children born into two-parent families, we have also attempted to estimate models that allow for family-specific trends using our sample of children born to single parents. Unfortunately, these models are not well-identified because for many of the families in the sample, there are relatively few observations available prior to the marriage. Our results provide some suggestive evidence that those mothers who do eventually marry have higher rates of income growth in the years prior to marriage than those who do not. Although the differential in the income growth rates is not statistically significant, the point estimate is fairly large, suggesting an annual income growth rate that is five percent higher among women who do eventually marry. Including family-specific trends reduces the estimated gains to marriage, but also makes the estimates extremely imprecise, so that we cannot statistically distinguish most coefficients between the two models (those with and without family-specific trends).

\section{How do Families Adjust to Changes in Family Structure?}

Our estimates indicate that the economic losses experienced by children living in single-parent families are substantial. ${ }^{18}$ These losses might be bigger still, however, if families failed to adjust their behavior in response to changes in family structure.

\footnotetext{
${ }^{18}$ Of course, our estimates tell us nothing about the distribution of resources within families. It may be that when resources decline parents reallocate in order to maintain their children's previous consumption levels. This is an important issue that deserves
} 
Consider the effects of divorce in the absence of any changes in labor supply, household structure (other than departure of one parent), or welfare receipt: assuming that children remain with their mothers, the mechanical effect would simply be the loss of the father's income. But resource losses could be much lower if family members draw on other income sources. In order to better understand how different potential behavioral responses combine to affect our estimated resource losses, we next look at individual components of income around the time of the change in family structure.

\section{A. Behavioral Responses to Divorce}

We begin our analysis of income components by estimating the average loss in father's earnings, which illustrates (approximately) what would happen to family income

if there were no behavioral responses. ${ }^{19}$ Here, we essentially re-estimate equation (2), but replace our dependent variables with father's earnings and look specifically at the first two years following divorce. Note that for this exercise we use income measured in levels rather than in logs, which leads to a larger estimated percentage income decline, but allows us to include cases in which the individual income components are equal to zero. The levels specification is not our preferred specification for the main analysis because a change in family structure is likely to have very different level effects on rich and poor families. The table defines time since the divorce relative to the most recent divorce, so that all observations in the "after" period are for children whose parents remain unmarried. The results produced by this exercise are shown in the first row of

further investigation but we know of no data on the distribution of family resources that follows families over time.

${ }^{19}$ More precisely, we use father's income within the child's household. In the years after a divorce in which the father has left the household, father's income is equal to zero. 
Table 4. In subsequent rows of the table we add child support, mother's earnings, welfare income, and the earnings of other household members to the income definition.

In the period 1 to 2 years after divorce, father's income falls to zero, which translates into an average loss of approximately $\$ 32,000$. This corresponds to an $83 \%$ loss in family income relative to the year before the divorce takes place. 0 Of course, it is not necessarily the case that father's income will disappear completely from the child's set of available resources since many fathers pay child support when they no longer reside in the household. The second row of Table 4 shows how divorce affects the sum of father's income and child support. Child support appears to replace a relatively small fraction of the income of the co-resident father. The loss of income from the father in the initial years after a divorce is approximately 12 percent lower when child support is included, or roughly $\$ 28,000$. The magnitude of this estimate is roughly consistent with average child support received, as reported by the Census Bureau, of approximately \$3700 in 1995 (U.S. Census Bureau, 1999).

One potentially important behavioral response following divorce is a change in mothers' labor supply. The next row of Table 4 adds mother's earnings to the measure of income used in row 2 , and shows that this response plays an important role in replacing the loss in resources following the father's departure. Adding mother's earnings to the income definition reduces the initial loss to approximately $\$ 25,000$ in the initial years after the divorce, which translates into a $63 \%$ loss in total family income. Of course this gain in income may come at the expense of spending time with her children and does not take additional child care expenses into account.

\footnotetext{
${ }^{20}$ Results for subsequent years are very similar and are available from the authors upon request.
} 
Along with increases in earned income, any take-up of public assistance for single mothers will further diminish the costs of divorce. Row 4 of Table 4 shows, however, that the extent to which transfer income mitigates the loss in fathers' income is small compared to the effect of child support and mother's earnings. When we add AFDC benefits to the income definition in the initial years after divorce the total income loss is further diminished by $\$ 700$.

At first glance, the estimated effect on total family income of adding income from other family members is puzzling (Row 5). One might expect that other family members, such as grandparents or aunts and uncles, would increase their contributions to the family following a relative's divorce. In fact, our estimate implies that the opposite is occurring. The result is driven by a few families who receive extremely high levels of income from other family members before the divorce occurs, and disappears when the top $1 \%$ of the distribution of other income (before the divorce) is removed from the sample.

\section{B. Behavioral Responses to Marriage}

In the last column of Table 4, we repeat the income decomposition for our sample of out-of-wedlock children whose mothers marry. The first row shows the increase in income that would occur if the only change resulting from marriage was the addition of a male partner. Father's earnings increase family income by approximately $\$ 17,000$ in the first two years after marriage, which would more than double total family income if all other income sources remained the same. ${ }^{1}$ The second row in the table considers whether the gains to marriage are reduced when we account for the fact that child support

\footnotetext{
${ }^{21}$ We refer to "father's income" although this may actually be step-father's income, or the income of a male cohabitor who is unrelated to the child.
} 
may have been received prior to marriage, and shows that for children born to singleparents child support plays a very limited role: adding child support to the income definition reduces the gains to marriage by less than $\$ 400$.

We next examine the extent to which an adjustment in mother's labor supply may alter the gains associated with marriage. As was the case with children born to two parent households, the mother's labor supply response has the largest impact on the estimated resource cost. The cost of single-parent status is estimated to be $\$ 4000$ or $25 \%$ lower than it would be if mothers did not increase their labor supply as a result of being without a live-in partner.

Unsurprisingly, AFDC plays a somewhat larger role maintaining income among out-of-wedlock children than among children who experience divorce. Including AFDC in the income definition reduces the estimated gains to marriage by roughly $\$ 1000$ (or $6 \%) .22$ Finally, the contribution of other family members also appears to be reduced when marriages occur. Including earnings of other family members reduces the gains to marriage by about $\$ 1000$.

\section{Conclusions}

Family structure has a significant impact on the economic resources that are available to children. In the long run, family income of children whose parents divorce and remain divorced for at least six years falls by 40 to $45 \%$ and food consumption is reduced by $17 \%$. Among the less-studied population of children born to single parents there is no evidence of an increase in food consumption, but those whose parents marry and remain married for at least six years experience post-tax income gains of $50 \%$ and 
pre-tax gains of $57 \%$. The more modest effects of living with a single parent on food consumption suggest that children's access to essentials may be somewhat better protected than estimates focused on income indicate.

While our estimated effects of family structure on income are large, three important points should be kept in mind. First, because the estimates are based on variation within the same families over time they are substantially smaller than estimates based on cross-sectional comparisons of different types of families. The frequency with which cross-sectional income comparisons motivate concern about family structure makes it important to recognize the extent to which they may overstate the true losses associated with living in a single-parent family.

Second, the estimated income changes, (as in most of the previous literature) do not apply to the typical child who experiences a parental divorce at a point in time, but rather to those whose parents are currently divorced. When we measure the reduction in resources six years after the first observed divorce, and so allow for the possibility of remarriage, we find income losses of 15 to $20 \%$, and consumption losses of just six percent. Similarly, the typical gains for a child born out-of-wedlock whose parent is currently married are smaller than the long-run effects cited above, since many marriages do not last.

Finally, it is important to note that while we estimate that single-parent families have substantially lower incomes than they would have if a second parent were in the household, these income losses do not necessarily translate into a decline in children's resources. Our model cannot inform us about the distribution of resources within families, and it may be that parents work hard to ensure that their children's needs are

22 This falls to about $\$ 600$ in the later years after marriage. 
met by disproportionately reducing their own resources when income falls. This is an important issue that deserves further investigation. Unfortunately, we do not know of any panel datasets that contain information on how resources are distributed within the household.

With this caveat, our findings suggest that family structure has a long-term impact on the economic resources that are available to children. The costs associated with growing up in single-parent families are not temporary but largely persist until a marriage or re-marriage occurs. This has important implications for public policy. Time limits recently imposed as part of welfare reform, for example, could result in substantive reductions in the economic well-being of children living in single-parent families. Furthermore, if income plays an important role in determining children's later success in life (which is matter of some debate), then our results suggest that policies that encourage two-parent families may be justified. 


\section{References}

Bane, Mary Jo, and Robert S. Weiss. 1980. "Alone Together: The World of SingleParent Families.” American Demographics, 2: 11-14, 48.

Bane, Mary Jo, and Ellwood, David. "Slipping Into and Out of Poverty: The Dynamics of Spells." Journal of Human Resources. 1986.

Bumpass, Larry L. and R. Kelly Raley. 1995. "Redefining Single-Parent Families:

Cohabitation and Changing Family Reality.” Demography, 32: 97-109.

Butrica, Barbara. 1998. "The Economics of the Family from a Dynamic Perspective." Syracuse University unpublished Ph.D. dissertation.

Cancian, Maria, and Deborah Reed. 2000. "Changes in Family Structure: Implications for Poverty and Related Policy.” Unpublished.

Charles, Kerwin Kofi and Melvin Stephens Jr. 2001. "Job Displacement, Disability and Divorce," Unpublished.

Duncan, Greg J. and Saul D. Hoffman. 1985a. "Economic Consequences of Marital Instability." In Horizontal Equity, Uncertainty, and Economic Well-Being. Chicago and London: University of Chicago Press.

Duncan, Greg J. and Saul D. Hoffman. 1985b. "A Reconsideration of the Economic Consequences of Marital Dissolution.” Demography, 22: 485-97.

Friedberg, Leora. 1998. "Did Unilateral Divorce Raise Divorce Rates? Evidence from Panel Data." American Economic Review, 88, 608-627.

Gallager, Maggie. 1996. The Abolution of Marriage: How We Destroy Lasting Love, Washington, D.C: Regnery.

Galston, William. 1996. "Divorce American Style," The Public Interest, 124: 12-26.

Gruber, Jonathan. 2000. “Is Making Divorce Easier Bad for Children?” National Bureau of Economic Research Working Paper \#7968.

Heckman, James, Robert LaLonde, and Jeffrey Smith. (1999). "The Economics and Econometrics of Active Labor Market Programs." in Handbook of Labor Economics. Volume 3A. Ed. Orley C. Ashenfelter and David Card. Amsterdam: Elsevier Science. 
Holden, Karen and Pamela J. Smock. 1991. “The Economics Costs of Marital Dissoluation: Why Do Women Bear a Disproportionate Cost?" Annual Review of Sociology 17:51-78.

Izan, Haji Y. 1980. “To Pool or Not to Pool: A Reexamination of Tobin's Food Demand Problem," Journal of Econometrics, 13: 391-402.

McLanahan, Sara and Lynne Casper. 1995. "Growing Diversity and Inequality in the American Family." State of the Union: America in the 1990's. New York: Russell Sage Foundation: 1-45.

McLanahan, Sara, and Gary Sandefur. 1994. Growing Up with a Single Parent: What Hurts, What Helps. Cambridge: Harvard University Press.

McLanahan, Sara. 1997. "Parent Absence or Poverty? Which Matters More?"

Consequences of Growing Up Poor. New York: Russell Sage Foundation: 35-48.

Maddala, G.S. 1971. "The Likelihood Approach to Pooling Cross-Section and TimeSeries Data," Econometrica, 39: 939-53.

Magnus, Jan R. and Mary S. Morgan, editors. 1997. Special Issue: The Experiment in Applied Econometrics, The Journal of Applied Econometrics, 12, 5.

Mayer, Susan. 1997. What Money Can’t Buy: Family Income and Children's Life Chances. Cambridge: Harvard University Press.

Meyer, Bruce, and James X. Sullivan. 2001. "The Effects of Welfare and Tax Reform: The Material Well-Being of Single Mothers in the 1980s and 1990s." unpublished. Northwestern University.

Ooms, Theodora. 1998. Toward More Perfect Unions: Putting Marriage on the Public Agenda, Washington, D.C., Family Impact Seminar.

Peterson, Richard R. 1989. Women, Work, and Divorce. New York: Suny.

Pollack, H. 1994. "Informal Transfers Within Families.” Ph.D. Thesis, John F. Kennedy School of Government, Harvard University.

Popenoe, David. 1996. Life Without Father: Compelling New Evidence that Fatherhood and Marriage are Indispensable for the Good of Children and Society, New York: Free Press.

Reilly, Siobhan and Eirik Evenhouse. 1997. "Divorce Laws and Divorce Rates: Evidence form Panel Data." Unpublished. 
Smock, Pamela, Wendy Manning and Sanjiv Gupta. 1999. "The Effect of Marriage and Divorce on Women's Economic Well-Being." American Sociological Review 64: 794812.

Spain, Daphne and Suzanne Bianchi. 1996. Balancing Act: Motherhood, Marriage and Employment among American Women. New York, Russell Sage.

Stirling, Kate. 1989. "Women Who Remain Divorced: The Long-term Economic Consequences,” Social Science Quarterly, 70: 549-61.

Tobin, James. 1950. "A Statistical Demand Function for Food in the U.S.A.," Journal of the Royal Statistical Society, 113, II: 113-141.

U.S. Census Bureau. 1999. Current Population Reports P60-196. "Child Support for Custodial Mothers and Fathers: 1995." Washington, D.C.

Waite, Linda. 1995. “Does Marriage Matter?” Demography, 32: 483-507.

Weiss, Robert S. 1984. "The Impact of Marital Dissolution on Income and Consumption of Single-Parent Households." Journal of Marriage and the Family.

Whitehead, Barbara Dafoe. 1996. The Divorce Culture: Rethinking our Commitments to Marriage and Family, New York: Vintage.

Zeldes, S. P. 1989. "Consumption and Liquidity Constraints: An Empirical Investigation.” Journal of Political Economy, 97: 305-346. 
Table 1. Sample Means in Year of Birth

\begin{tabular}{|c|c|c|c|c|}
\hline & \multicolumn{2}{|c|}{ Born into Two Parent Family } & \multicolumn{2}{|c|}{ Born into Single Parent Family } \\
\hline & $\begin{array}{l}\text { Remain in Two } \\
\text { Parent Family }\end{array}$ & $\begin{array}{l}\text { Parents } \\
\text { Divorce }\end{array}$ & $\begin{array}{c}\text { Remain } \\
\text { in Single } \\
\text { Parent Family }\end{array}$ & $\begin{array}{c}\text { Parent Eventually } \\
\text { Marries }\end{array}$ \\
\hline Pre-tax Family Income & $\begin{array}{l}40,964 \\
(25243)\end{array}$ & $\begin{array}{c}33,852 \\
(24977)\end{array}$ & $\begin{array}{c}17,907 \\
(19081)\end{array}$ & $\begin{array}{l}17,218 \\
(15165)\end{array}$ \\
\hline Post-tax Family Income & $\begin{array}{c}30,778 \\
(17347)\end{array}$ & $\begin{array}{c}24,864 \\
(13460)\end{array}$ & $\begin{array}{c}16,162 \\
(15435)\end{array}$ & $\begin{array}{c}16,718 \\
(14324)\end{array}$ \\
\hline Food Consumption & $\begin{array}{c}5877 \\
(2778)\end{array}$ & $\begin{array}{c}5284 \\
(2380)\end{array}$ & $\begin{array}{l}4430 \\
(2795)\end{array}$ & $\begin{array}{l}4285 \\
(2920)\end{array}$ \\
\hline $\begin{array}{l}\text { Mother's ed <= High } \\
\text { School }\end{array}$ & $\begin{array}{l}0.551 \\
(0.50)\end{array}$ & $\begin{array}{l}0.624 \\
(0.49)\end{array}$ & $\begin{array}{c}0.78 \\
(0.41)\end{array}$ & $\begin{array}{c}0.72 \\
(0.45)\end{array}$ \\
\hline Black & $\begin{array}{l}0.081 \\
(0.27)\end{array}$ & $\begin{array}{c}0.11 \\
(0.31)\end{array}$ & $\begin{array}{c}0.63 \\
(0.48)\end{array}$ & $\begin{array}{c}0.35 \\
(0.48)\end{array}$ \\
\hline $\begin{array}{l}\text { Maximum AFDC Benefit } \\
\text { for Family of Four }\end{array}$ & $\begin{array}{l}7808 \\
(2990)\end{array}$ & $\begin{array}{c}7805 \\
(3133)\end{array}$ & $\begin{array}{c}6657 \\
(3004)\end{array}$ & $\begin{array}{c}7344 \\
(3102)\end{array}$ \\
\hline Family Size & $\begin{array}{c}4.14 \\
(1.32)\end{array}$ & $\begin{array}{c}3.92 \\
(1.10)\end{array}$ & $\begin{array}{c}4.42 \\
(2.02)\end{array}$ & $\begin{array}{c}3.74 \\
(1.90)\end{array}$ \\
\hline $\begin{array}{l}\text { Number of Children in } \\
\text { Sample }\end{array}$ & 6228 & 1235 & 1606 & 483 \\
\hline
\end{tabular}

Note: Standard deviations in parenthesis 
Table 2. Estimated Economic Consequences Associated with Single Parent Family Status Children Born into Two Parent Families

\begin{tabular}{|c|c|c|c|c|c|c|}
\hline \multirow[b]{2}{*}{$\begin{array}{l}\text { Years Before } \\
\text { or After Divorce }\end{array}$} & \multicolumn{3}{|c|}{ Year Since First Divorce } & \multicolumn{3}{|c|}{ Year Since Last Divorce } \\
\hline & $\begin{array}{c}\text { Log } \\
\text { Income }\end{array}$ & $\begin{array}{c}\text { Log } \\
\text { After-tax Income }\end{array}$ & $\begin{array}{c}\text { Log } \\
\text { Consumption }\end{array}$ & $\begin{array}{c}\text { Log } \\
\text { Income }\end{array}$ & $\begin{array}{c}\text { Log } \\
\text { After-tax Income }\end{array}$ & $\begin{array}{c}\text { Log } \\
\text { Consumption }\end{array}$ \\
\hline 2 years before & $\begin{array}{c}\mathbf{- 0 . 0 1 1} \\
(0.059) \\
-0.011\end{array}$ & $\begin{array}{c}\mathbf{- 0 . 0 0 8} \\
(0.056) \\
-0.008\end{array}$ & $\begin{array}{c}\mathbf{0 . 0 1 0} \\
(0.045) \\
0.010\end{array}$ & $\begin{array}{c}\mathbf{0 . 0 0 0} \\
(0.058) \\
0.000\end{array}$ & $\begin{array}{c}\mathbf{0 . 0 1 8} \\
(0.055) \\
0.018\end{array}$ & $\begin{array}{c}\mathbf{0 . 0 1 3} \\
(0.045) \\
0.013\end{array}$ \\
\hline 1 year before & $\begin{array}{c}\mathbf{- 0 . 0 5 2} \\
(0.052) \\
-0.051\end{array}$ & $\begin{array}{c}\mathbf{- 0 . 0 2 8} \\
(0.049) \\
-0.028\end{array}$ & $\begin{array}{c}\mathbf{- 0 . 1 3 4} \\
(0.061) \\
-0.125\end{array}$ & $\begin{array}{c}\mathbf{- 0 . 0 4 5} \\
(0.050) \\
-0.044\end{array}$ & $\begin{array}{c}\mathbf{- 0 . 0 2 2} \\
(0.048) \\
-0.022\end{array}$ & $\begin{array}{c}\mathbf{- 0 . 1 3 2} \\
(0.061) \\
-0.124\end{array}$ \\
\hline Year of Divorce & $\begin{array}{c}\mathbf{- 0 . 3 5 6} \\
(0.070) \\
-0.300\end{array}$ & $\begin{array}{c}\mathbf{- 0 . 2 4 1} \\
(0.065) \\
-0.214\end{array}$ & $\begin{array}{c}\mathbf{- 0 . 3 4 8} \\
(0.066) \\
-0.294\end{array}$ & $\begin{array}{c}\mathbf{- 0 . 3 6 0} \\
(0.068) \\
-0.302\end{array}$ & $\begin{array}{c}\mathbf{- 0 . 2 4 6} \\
(0.065) \\
-0.218\end{array}$ & $\begin{array}{c}\mathbf{- 0 . 3 4 6} \\
(0.067) \\
-0.292\end{array}$ \\
\hline 1 year after & $\begin{array}{c}\mathbf{- 0 . 5 4 1} \\
(0.072) \\
-0.418\end{array}$ & $\begin{array}{c}\mathbf{- 0 . 3 8 9} \\
(0.066) \\
-0.322\end{array}$ & $\begin{array}{c}\mathbf{- 0 . 2 0 3} \\
(0.055) \\
-0.184\end{array}$ & $\begin{array}{c}\mathbf{- 0 . 6 9 2} \\
(0.072) \\
-0.499\end{array}$ & $\begin{array}{c}\mathbf{- 0 . 5 1 4} \\
(0.070) \\
-0.402\end{array}$ & $\begin{array}{c}\mathbf{- 0 . 2 5 2} \\
(0.052) \\
-0.223\end{array}$ \\
\hline 2 years after & $\begin{array}{c}\mathbf{- 0 . 3 8 6} \\
(0.072) \\
-0.320\end{array}$ & $\begin{array}{c}\mathbf{- 0 . 2 6 0} \\
(0.071) \\
-0.229\end{array}$ & $\begin{array}{c}\mathbf{- 0 . 1 5 6} \\
(0.056) \\
-0.144\end{array}$ & $\begin{array}{c}\mathbf{- 0 . 5 9 5} \\
(0.074) \\
-0.448\end{array}$ & $\begin{array}{c}\mathbf{- 0 . 4 3 1} \\
(0.080) \\
-0.350\end{array}$ & $\begin{array}{c}\mathbf{- 0 . 2 4 1} \\
(0.064) \\
-0.214\end{array}$ \\
\hline 3 years after & $\begin{array}{c}\mathbf{- 0 . 3 0 2} \\
(0.080) \\
-0.261\end{array}$ & $\begin{array}{c}\mathbf{- 0 . 1 9 5} \\
(0.074) \\
-0.177\end{array}$ & $\begin{array}{c}\mathbf{- 0 . 1 6 9} \\
(0.069) \\
-0.155\end{array}$ & $\begin{array}{c}\mathbf{- 0 . 6 2 2} \\
(0.072) \\
-0.463\end{array}$ & $\begin{array}{c}\mathbf{- 0 . 4 5 5} \\
(0.085) \\
-0.366\end{array}$ & $\begin{array}{c}\mathbf{- 0 . 2 6 6} \\
(0.090) \\
-0.234\end{array}$ \\
\hline 4 year after & $\begin{array}{c}\mathbf{- 0 . 2 0 5} \\
(0.081) \\
-0.185\end{array}$ & $\begin{array}{c}\mathbf{- 0 . 1 0 8} \\
(0.071) \\
-0.102\end{array}$ & $\begin{array}{c}\mathbf{- 0 . 1 3 8} \\
(0.055) \\
-0.129\end{array}$ & $\begin{array}{c}\mathbf{- 0 . 5 4 7} \\
(0.064) \\
-0.421\end{array}$ & $\begin{array}{c}\mathbf{- 0 . 3 7 4} \\
(0.078) \\
-0.312\end{array}$ & $\begin{array}{c}\mathbf{- 0 . 2 2 1} \\
(0.066) \\
-0.198\end{array}$ \\
\hline 5 year after & $\begin{array}{c}\mathbf{- 0 . 2 8 2} \\
(0.098) \\
-0.246\end{array}$ & $\begin{array}{c}\mathbf{- 0 . 1 9 4} \\
(0.081) \\
-0.176\end{array}$ & $\begin{array}{c}\mathbf{- 0 . 1 0 2} \\
(0.054) \\
-0.097\end{array}$ & $\begin{array}{c}\mathbf{- 0 . 6 7 4} \\
(0.079) \\
-0.490\end{array}$ & $\begin{array}{c}\mathbf{- 0 . 5 0 5} \\
(0.085) \\
-0.396\end{array}$ & $\begin{array}{c}\mathbf{- 0 . 2 1 1} \\
(0.062) \\
-0.190\end{array}$ \\
\hline $\begin{array}{l}6 \text { or more years } \\
\text { after }\end{array}$ & $\begin{array}{c}\mathbf{- 0 . 2 2 0} \\
(0.085) \\
-0.197\end{array}$ & $\begin{array}{c}\mathbf{- 0 . 1 6 5} \\
(0.082) \\
-0.152\end{array}$ & $\begin{array}{c}\mathbf{- 0 . 0 6 0} \\
(0.046) \\
-0.058\end{array}$ & $\begin{array}{c}\mathbf{- 0 . 5 9 9} \\
(0.082) \\
-0.451\end{array}$ & $\begin{array}{c}\mathbf{- 0 . 5 1 7} \\
(0.082) \\
-0.404\end{array}$ & $\begin{array}{c}\mathbf{- 0 . 1 8 0} \\
(0.059) \\
-0.165\end{array}$ \\
\hline $\begin{array}{l}\text { Number of } \\
\text { Observations }\end{array}$ & 48111 & 48111 & 46523 & 48111 & 48111 & 46523 \\
\hline
\end{tabular}

Note: Standard errors in parentheses. Percentage effect in italics. 
Table 3. Estimated Economic Consequences Associated with Single Parent Family Status Children Born into Single Parent Families

\begin{tabular}{|c|c|c|c|c|c|c|}
\hline \multirow[b]{2}{*}{$\begin{array}{l}\text { Years Before } \\
\text { or After Marriage }\end{array}$} & \multicolumn{3}{|c|}{ Year Since First Marriage } & \multicolumn{3}{|c|}{ Year Since Last Marriage } \\
\hline & $\begin{array}{c}\text { Log } \\
\text { Income }\end{array}$ & $\begin{array}{c}\text { Log } \\
\text { After-tax Income }\end{array}$ & $\begin{array}{c}\log \\
\text { Consumption } \\
\end{array}$ & $\begin{array}{c}\text { Log } \\
\text { Income }\end{array}$ & $\begin{array}{c}\text { Log } \\
\text { After-tax Income }\end{array}$ & $\begin{array}{c}\log \\
\text { Consumption } \\
\end{array}$ \\
\hline 2 years before & $\begin{array}{c}\mathbf{0 . 0 8 4} \\
(0.104) \\
0.088\end{array}$ & $\begin{array}{c}\mathbf{0 . 0 8 1} \\
(0.103) \\
0.084\end{array}$ & $\begin{array}{c}\mathbf{- 0 . 1 6 1} \\
(0.124) \\
-0.149\end{array}$ & $\begin{array}{c}\mathbf{0 . 0 9 9} \\
(0.103) \\
0.104\end{array}$ & $\begin{array}{c}\mathbf{0 . 0 9 4} \\
(0.101) \\
0.099\end{array}$ & $\begin{array}{c}\mathbf{- 0 . 1 6 4} \\
(0.124) \\
-0.151\end{array}$ \\
\hline 1 year before & $\begin{array}{c}\mathbf{- 0 . 1 0 2} \\
(0.175) \\
-0.097\end{array}$ & $\begin{array}{c}\mathbf{0 . 1 0 7} \\
(0.174) \\
0.113\end{array}$ & $\begin{array}{c}\mathbf{- 0 . 0 4 9} \\
(0.071) \\
-0.047\end{array}$ & $\begin{array}{c}\mathbf{- 0 . 0 8 2} \\
(0.173) \\
-0.079\end{array}$ & $\begin{array}{c}\mathbf{- 0 . 0 8 8} \\
(0.172) \\
-0.084\end{array}$ & $\begin{array}{c}\mathbf{- 0 . 0 5 1} \\
(0.070) \\
-0.049\end{array}$ \\
\hline Year of Marriage & $\begin{array}{l}\mathbf{0 . 5 0 6} \\
(0.130) \\
0.658\end{array}$ & $\begin{array}{l}\mathbf{0 . 4 7 1} \\
(0.126) \\
0.602\end{array}$ & $\begin{array}{c}\mathbf{0 . 1 5 7} \\
(0.066) \\
0.170\end{array}$ & $\begin{array}{c}\mathbf{0 . 5 2 7} \\
(0.128) \\
0.693\end{array}$ & $\begin{array}{c}\mathbf{0 . 4 9 0} \\
(0.124) \\
0.633\end{array}$ & $\begin{array}{c}\mathbf{0 . 1 4 6} \\
(0.067) \\
0.157\end{array}$ \\
\hline 1 year after & $\begin{array}{c}\mathbf{0 . 4 2 6} \\
(0.131) \\
0.531\end{array}$ & $\begin{array}{c}\mathbf{0 . 3 8 9} \\
(0.127) \\
0.476\end{array}$ & $\begin{array}{c}\mathbf{- 0 . 0 3 3} \\
(0.082) \\
-0.032\end{array}$ & $\begin{array}{c}\mathbf{0 . 4 6 5} \\
(0.126) \\
0.592\end{array}$ & $\begin{array}{c}\mathbf{0 . 4 2 6} \\
(0.122) \\
0.531\end{array}$ & $\begin{array}{c}\mathbf{- 0 . 0 1 2} \\
(0.083) \\
-0.012\end{array}$ \\
\hline 2 years after & $\begin{array}{l}\mathbf{0 . 3 2 7} \\
(0.131) \\
0.387\end{array}$ & $\begin{array}{c}\mathbf{0 . 3 0 0} \\
(0.127) \\
0.349\end{array}$ & $\begin{array}{c}\mathbf{- 0 . 0 7 5} \\
(0.088) \\
-0.073\end{array}$ & $\begin{array}{l}\mathbf{0 . 4 7 1} \\
(0.118) \\
0.602\end{array}$ & $\begin{array}{l}\mathbf{0 . 4 3 2} \\
(0.115) \\
0.541\end{array}$ & $\begin{array}{c}\mathbf{0 . 0 0 3} \\
(0.093) \\
0.003\end{array}$ \\
\hline 3 years after & $\begin{array}{l}\mathbf{0 . 3 1 9} \\
(0.135) \\
0.375\end{array}$ & $\begin{array}{c}\mathbf{0 . 2 9 1} \\
(0.130) \\
0.338\end{array}$ & $\begin{array}{c}\mathbf{- 0 . 0 7 3} \\
(0.097) \\
-0.071\end{array}$ & $\begin{array}{l}\mathbf{0 . 5 0 2} \\
(0.126) \\
0.653\end{array}$ & $\begin{array}{c}\mathbf{0 . 4 5 9} \\
(0.122) \\
0.583\end{array}$ & $\begin{array}{c}\mathbf{- 0 . 0 6 8} \\
(0.088) \\
-0.066\end{array}$ \\
\hline 4 year after & $\begin{array}{l}\mathbf{0 . 2 5 1} \\
(0.139) \\
0.286\end{array}$ & $\begin{array}{c}\mathbf{0 . 2 2 5} \\
(0.135) \\
0.252\end{array}$ & $\begin{array}{l}\mathbf{0 . 0 0 3} \\
(0.084) \\
0.003\end{array}$ & $\begin{array}{l}\mathbf{0 . 5 0 8} \\
(0.125) \\
0.663\end{array}$ & $\begin{array}{c}\mathbf{0 . 4 6 3} \\
(0.121) \\
0.589\end{array}$ & $\begin{array}{c}\mathbf{0 . 0 0 3} \\
(0.086) \\
0.003\end{array}$ \\
\hline 5 year after & $\begin{array}{l}\mathbf{0 . 2 3 9} \\
(0.141) \\
0.270\end{array}$ & $\begin{array}{l}\mathbf{0 . 2 1 0} \\
(0.138) \\
0.234\end{array}$ & $\begin{array}{c}\mathbf{- 0 . 0 2 2} \\
(0.090) \\
-0.022\end{array}$ & $\begin{array}{l}\mathbf{0 . 4 7 1} \\
(0.135) \\
0.602\end{array}$ & $\begin{array}{l}\mathbf{0 . 4 2 9} \\
(0.130) \\
0.536\end{array}$ & $\begin{array}{l}\mathbf{0 . 0 0 2} \\
(0.089) \\
0.002\end{array}$ \\
\hline $\begin{array}{l}6 \text { or more years } \\
\text { after }\end{array}$ & $\begin{array}{l}\mathbf{0 . 2 8 6} \\
(0.170) \\
0.331\end{array}$ & $\begin{array}{l}\mathbf{0 . 2 5 0} \\
(0.166) \\
0.284\end{array}$ & $\begin{array}{r}\mathbf{- 0 . 0 1 0} \\
(0.096) \\
-0.010\end{array}$ & $\begin{array}{c}\mathbf{0 . 4 5 3} \\
(0.187) \\
0.573\end{array}$ & $\begin{array}{l}\mathbf{0 . 4 0 2} \\
(0.184) \\
0.495\end{array}$ & $\begin{array}{c}\mathbf{0 . 0 2 0} \\
(0.098) \\
0.020\end{array}$ \\
\hline
\end{tabular}

Note: Standard errors in parentheses. Percentage effect in italics. 
Table 4. Components of Income Change Associated with Changes in Family Structure

\begin{tabular}{|c|c|c|c|c|c|}
\hline & & $\begin{array}{c}1 \text { year before } \\
\text { divorce }\end{array}$ & $\begin{array}{c}\text { 1-2 years } \\
\text { after divorce }\end{array}$ & $\begin{array}{c}1 \text { year before } \\
\text { marriage }\end{array}$ & $\begin{array}{c}1-2 \text { years } \\
\text { after marriage }\end{array}$ \\
\hline \multicolumn{6}{|c|}{ Dependent variable } \\
\hline \multirow[t]{2}{*}{ (1) } & father's earnings & & $-\$ 32,231$ & & $\$ 17,211$ \\
\hline & & & $(5018)$ & & $(1534)$ \\
\hline \multirow[t]{2}{*}{ (2) } & (1) + child support received & & $-\$ 28,237$ & & $\$ 16,892$ \\
\hline & & & $(4133)$ & & $(1554)$ \\
\hline \multirow[t]{2}{*}{ (3) } & (2) + mother's earnings & & $-\$ 24,563$ & & $\$ 12,758$ \\
\hline & & & $(4025)$ & & $(2309)$ \\
\hline \multirow[t]{2}{*}{ (4) } & (3) + afdc of head \& wife & & $-\$ 23,841$ & & $\$ 11,777$ \\
\hline & & & (4042) & & $(2008)$ \\
\hline \multirow[t]{2}{*}{ (5) } & (4) + earnings of others & & $-\$ 26,737$ & & $\$ 10,798$ \\
\hline & & & $(4396)$ & & $(2224)$ \\
\hline \multirow[t]{2}{*}{ (6) } & total family income & & $-\$ 26,760$ & & $\$ 10,534$ \\
\hline & & & $(4220)$ & & $(2517)$ \\
\hline \multicolumn{2}{|c|}{ Average family income } & $\$ 38,708$ & & $\$ 16,223$ & \\
\hline
\end{tabular}

